\title{
Callogenesis and Embryogenic Potential of New Superior Cocoa (Theobroma cacao L.) Genotypes Treated with Ascorbic Acid
}

\author{
Sulistyani Pancaningtyas ${ }^{\left.1^{*}\right)}$ \\ ${ }^{1)}$ Indonesian Coffee and Cocoa Research Institute, Jl. PB. Sudirman 90, Jember, Indonesia \\ ${ }^{*}$ Corresponding author: listya.1606@gmail.com \\ Received: 28 June 2021 / Accepted: 14 October 2021
}

\begin{abstract}
Clonal propagation is an alternative method of maintaining the genetic purity of superior cocoa plants (Theobroma cacao L.). The somatic embryogenesis technique is likely the most effective and efficient method for plant propagation. This study aimed at investigating the callogenesis and embryogenic potential of new superior cocoa clones on culture media added with various concentrations of antioxidants and variation in the concentration of auxin hormone combined with ascorbic acid. The superior clones used in this study were MCC 01, MCC 02, Sulawesi 03, ICCRI 07, and ICCRI 09. The parameters observed in this study were percentage of embryogenic callus formation, number of secondary somatic embryos, and percentage of embryo somatic cells that develop into planlets. The addition of 2,4,5-T combined with ascorbic acid affected the initiation of cocoa secondary somatic embryogenesis. Treatment combination of ascorbic acid $100 \mathrm{mg} . \mathrm{L}^{-1}$ and 2,4,5-T $1 \mathrm{mg} . \mathrm{L}^{-1}$ had a significant effect on the initiation of secondary somatic embryogenesis of cocoa in the embryogenic callus phase $(4.73 \%)$, globular embryos $(2.53 \%)$, torpedo embryos $(4.67 \%)$ and sprouts $(0.47 \%)$. Three clones i.e ICCRI 07, Sulawesi 03 and ICCRI 09 clones showed a higher percentage $(3.0 \%, 2.10 \%$, and $1.80 \%$, respectively) of embryogenic callus growth than the other clones. Meanwhile, on MCC 01 clone, all treatments did not affect the regeneration of embryogenic callus. The combination treatment of organic acid and adenine showed a low embryogenic callus response in MCC 01 and MCC 02 clones. However, MCC 02 clone also did not show a response in form of globular, torpedo, and germination phase somatic embryo regenerations. This indicates that different plant cultivars show different responses to the addition of organic acids. Treatment combinations of adenine $0.0125 \mathrm{mg} . \mathrm{L}^{-1}+$ ascorbic acid $100 \mathrm{mg} . \mathrm{L}^{-1}$ gave the best response to the regeneration of somatic embryos for the globular, torpedo, and germination stages, started 3 weeks after being transferred to regeneration medium.
\end{abstract}

Keywords: somatic embryogenesis, cocoa, in vitro, somatic embryo, ascorbic acid, browning

\section{INTRODUCTION}

Theobroma cacao L. is one of the important plantation commodities that has significant economic value for the chocolate industry in the world (Squicciarini \& Swinnen, 2016). ICCO (2020) shows that world cocoa production in 2019-2020 decreased by 4.750 million tons compared to 2018-2019 (4.780 million tons). The reason behind this decline in production is caused by the reduced number of cocoa plantations and the decrease in crop productivity.

Along with its development, in addition to the aging of cocoa trees and high input costs, there are several obstacles in cocoa 
cultivation related to abiotic stress problems such as drought (Towaha \& Wardiana, 2015) and biotic stress such as pests and diseases attack that affect cocoa productivity. Development of superior cocoa clones that have resistance to biotic stress in form of pests and diseases can be obtained through a breeding program carried out periodically and continuously from genetic materials, which may provide opportunities for genetic conservation of cocoa plants. Environmental stress might be caused by both biotic and abiotic factor.

Procurement of superior planting materials conventionally often facing problems because it is difficult to get hight quality seedlings in large quantities and in a short time. According to Pancaningtyas (2013), cocoa somatic embryogenesis is a tissue culture technique that produces primary embryos from cocoa plant organs, i.e. the flower parts (staminodes and petals). This technique has several advantages over conventional propagation techniques for large-scale plant propagation while maintaining genetic stability and integrity, i.e., obtaining plants with a uniform genotype in large numbers and in a short time (Maximova et al., 2002; Quainoo \& Dwomo, 2012).

The development of this technology to date has produced plantlets with a conversion rate of $65 \%$ and relatively low percentage of somaclonal variation (Lopez et al., 2010). Modifications related to the growth medium for somatic embryogenesis (SE) have been reported recently by Kouassi et al. (2017) and Modeste et al. (2017). Further development of SE protocol modified by various commercial companies has been outlined in various international patent documents (Wickramasuriya \& Dunwell, 2018). Despite continuous progress, the low reproducibility and regeneration efficiency of the developed methods and the differences in responses between genotypes in the SE process are still challenges for mass propagation of elite cocoa plants on a commer- cial scale (da Silva et al., 2008). The diversity of responses to somatic embryogenesis is mainly due to differences in genotypes (Issali et al., 2008; Kouassi et al., 2017).

However, variation of somatic embryos for each cocoa genotype is one of the obstacles that must be overcome. The application of somatic embryogenesis in cocoa plants is considered to be quite complicated due to the recalcitrant character of cocoa seed and plant genetics that affect the ability of gene expression to regenerate. Recalcitrant is defined as the inability of plant cells, tissues, and organs to thrive in tissue culture (Benson, 2000). One of the components that affect the disability in vitro is the high phenol content and phenol oxidase compounds. Oxidation of this compound is an inhibiting factor for multiplication and tissue regeneration. The ability of embryogenesis is also influenced by the concentration and distribution of polyphenolic compounds (Gallego et al., 2016). High concentrations of phenolic compounds are associated with non-regenerating responses of somatic embryos (Alemanno et al., 2003). These compounds can further inhibit the development of plant tissue in vitro. The addition of polyvinylpyrrolidone (PVP) and antioxidants such as ascorbic acid and citric acid is a way to inhibit the production of phenolic compounds or reduce their accumulation in tissue culture media (Krishna et al., 2008). Overcoming this bottleneck requires optimization of existing protocols.

Application of the somatic embryogenesis protocol to new superior cocoa clones requires optimization at the secondary embryogenic callus regeneration stage, which is the most important stage in somatic embryo production. Therefore, this study aimed to evaluate the callogenesis and embryogenic potential of new superior cocoa clones on culture media equipped with various concentrations of antioxidants and variations in the concentration of auxin hormone. 


\section{MATERIALS AND METHODS}

The genotypes used in this study were Sulawesi 03, MCC 01, MCC 02, ICCRI 07, and ICCRI 09. Each clone used 100 budding flowers. The used as explants material were cocoa flower parts.

This research was carried out at the Biotechnology Laboratory of the Indonesian Coffee and Cocoa Research Institute, taking place from February 2019 to December 2020. Research on cocoa propagation through the somatic embryogenesis technique was carried out in integrated procedures, starting from mother tree selection, explant collection, flower induction, primary embryo production, embryogenic callus initiation, embryogenic callus multiplication, secondary embryo production, germination, and planlet maturation. The initial stage of laboratory works begans with the orientation of the medium used for each stage of development. Different stages require different culture mediums, as well as different genotype, require different medium.

The growing medium used in the cocoa genotypes protocol included modified Murashige and Skoog, and Driver and Kuniyuki basal medium, PGR (2,4-D, 2,4,5-T, kinetin, adenine sulfate, NAA, IBA), ascorbic acid, glucose, sucrose, gelrite, aquadest, sodium hypochlorite $10 \%$, aluminum foil, $\mathrm{NaOH}, \mathrm{HCl}$, alcohol.

\section{Embryogenic Callus Initiation}

Primary embryos obtained from the previous stage were re-initiated to produce secondary embryogenic callus, incubated for eight weeks in the dark at $25^{\circ} \mathrm{C}$. Secondary embryogenesis was used to increase the number and quality of somatic embryos produced (Maximova et al., 2002). The culture medium used consisted of a combination of basic media Murashige and Skoog (1962) and Driver \& Kuniyuki (1984), adenine sulfate $0.25 \mathrm{mg} . \mathrm{L}^{-1}$, glycine $2 \mathrm{mg} . \mathrm{L}^{-1}$, L-lycine 0.40 mg.L $\mathrm{L}^{-1}$, L-leucine $0.40 \mathrm{mg} . \mathrm{L}^{-1}$, L-arginine $0.40 \mathrm{mg} . \mathrm{L}^{-1}$, L-tryptophan $0.20 \mathrm{mg} \cdot \mathrm{L}^{-1}$. Embryogenic callus from each cocoa clone had a different regeneration rate. Therefore, the addition of ascorbic acid antioxidant treatment and variations in the concentration of auxin $(2,4,5-\mathrm{T})$ in the growing media were as following:

M0 (Control/embryogenic callus initiation medium - SEC).

M1 (ascorbic acid 100 mg. $\mathrm{L}^{-1}+2,4,5-\mathrm{T} 0.5$ mg. $\left.\mathrm{L}^{-1}\right)$.

M2 (ascorbic acid 100 mg.L $\mathrm{L}^{-1}+$ 2,4,5-T 1 mg. $\left.L^{-1}\right)$.

M3 (ascorbic acid $200 \mathrm{mg} . \mathrm{L}^{-1}+2,4,5-\mathrm{T} 0.5$ mg. $\left.L^{-1}\right)$.

M4 (ascorbic acid 200 mg.L $\mathrm{L}^{-1}+2,4,5-\mathrm{T} 1$ mg. $\left.L^{-1}\right)$.

The study was arranged according to a factorial completely randomized design, were the first factor was five cocoa clones (Sulawesi 03, MCC 01, MCC 02, ICCRI 07, and ICCRI 09) and the second factor was five types of media with three replications. The total treatment combinations were 75 . Furthermore, analysis of variance was carried out using Duncan multiple range test at $5 \%$ significant level. The characteristics of embryogenic callus are having a friable structure and forming crystals like dew. The formation of the embryogenic callus is an important key in the somatic embryogenesis process of propagation. The optimal time for secondary embryogenic maintenance is 21 to 26 weeks after initiation of the primary embryo (Maximova et al., 2002). 


\section{Somatic Embryo Regeneration}

This stage is a process for the formation of somatic embryos derived from secondary embryogenic callus. Multiplicated embryogenic callus was sub-cultured on expression media with balanced hormone composition. This process lasted for four weeks in the dark. Embryos that have been formed were maintained until they were ready to be harvested. The characteristics of normal embryos that are ready to be harvested are embryos in the torpedo-cotyledon phase. At this stage, there is still a diversity of various stages of embryonic growth produced, including the globular phase to the cotyledon phase. Embryos before the torpedo phase and the cotyledon phase were sub-cultured on the same medium.

Phenolic oxidation is one of the obstacles in the propagation of cocoa embryogenesis. To overcome this problem, organic acid was added to increase the potential of somatic embryos from the resulting callus biomass. The formulation of the media for enhancing the regeneration of embryos from biomass with the addition of organic acids, as follows:

Media C0 (Control /expression medium)

Media C1 (adenin $0.025 \mathrm{mg} . \mathrm{L}^{-1}+$ ascorbic acid $\left.50 \mathrm{mg} . \mathrm{L}^{-1}\right)$

Media C2 (adenin $0.0125 \mathrm{mg} . \mathrm{L}^{-1}+$ ascorbic acid $\left.50 \mathrm{mg} . \mathrm{L}^{-1}\right)$

Media C3 (adenin $0.025 \mathrm{mg} . \mathrm{L}^{-1}+$ ascorbic acid $100 \mathrm{mg} . \mathrm{L}^{-1}$ )

Media C4 (adenin 0.0125 mg. $\mathrm{L}^{-1}+$ ascorbic acid $100 \mathrm{mg} . \mathrm{L}^{-1}$ )

Media C5 (adenin 0.025 mg. $\mathrm{L}^{-1}+$ ascorbic acid $\left.150 \mathrm{mg} . \mathrm{L}^{-1}\right)$

Media C6 (adenin 0.0125 mg. $\mathrm{L}^{-1}+$ ascorbic acid $\left.150 \mathrm{mg} . \mathrm{L}^{-1}\right)$

The study was arranged according to a factorial completely randomized design
(CRD), the first factor was four cocoa clones (MCC 01, MCC 02, Sulawesi 03, and ICCRI 09) and the second factor was seven types of media with three replications. The total treatment combinations were 84 . Further, analysis of variance will be carried out using DMRT at 5\% level.

\section{Observation Method}

Several parameters were observed in this study. Observation of secondary embryogenic callus percentage was carried out started at eight weeks after culture on secondary embryogenic callus initiation media (SEC).

$\%$ embryogenic callus $=$

$$
\frac{\text { total embryogenic callus }}{\text { total explants }} \times 100
$$

Percentage of secondary somatic embryos was observed when $\pm 3 \mathrm{~g}$ of embryogenic callus clusters were cultured on the expression medium for somatic embryo formation. Observations were carried out qualitatively using a microscope and quantitatively by counting the number of embryos produced by each embryogenic callus cluster. Observations were made at four weeks after culture in embryo regeneration medium.

$\%$ somatic embryos $=$

$$
\frac{\text { total somatic embryos }}{\text { total explants }} \times 100
$$

\section{RESULTS AND DISCUSSION}

\section{Embryogenesis Process}

The process of embryogenesis in cocoa is secondary somatic embryogenesis, where the resulting primary somatic embryo is reinitiated to produce secondary somatic embryos. At this initiation stage, there are regeneration constraints that are mainly caused by the oxi- 
dation of phenolic compounds which causes browning in the explants (Figure 2). Browning is one of the obstacles in in-vitro culture caused by the accumulation of phenolic compounds due to polyphenol oxidase (PPO) oxidation (Jones \& Saxena, 2013). Browning in explant tissue is the main obstacle at this stage. In addition, variations in the content of endogenous hormones also affect the rate of regeneration of embryogenic callus. Based on Pancaningtyas (2015) the highest content of phenolic compounds was at the embryogenic callus stage. The addition of organic acids in in-vitro culture media was carried out to overcome the inhibition of phenolic compounds so that the explants could increase their regeneration to produce somatic embryos.
In the first secondary embryogenesis observation (3 weeks after initiation), ICCRI 07, Sulawesi 03, and ICCRI 09 clones showed a higher percentage of embryogenic callus growth compared to the other clones $(3.0 \%$, $2.10 \%$, and $1.80 \%$ ). Meanwhile, in the MCC 01 clone, all treatments did not affect the regeneration of embryogenic callus. In the further regeneration of secondary somatic embryogenesis, Sulawesi 03 clones showed a higher percentage of secondary somatic embryo formation both at the globular and torpedo stage and even at shoot growth at the $9^{\text {th }}$ week of observation (Figure 2). Based on these data, genotype differences greatly influence the initiation of secondary somatic embryogenesis. The effect of genotypes had a significant effect
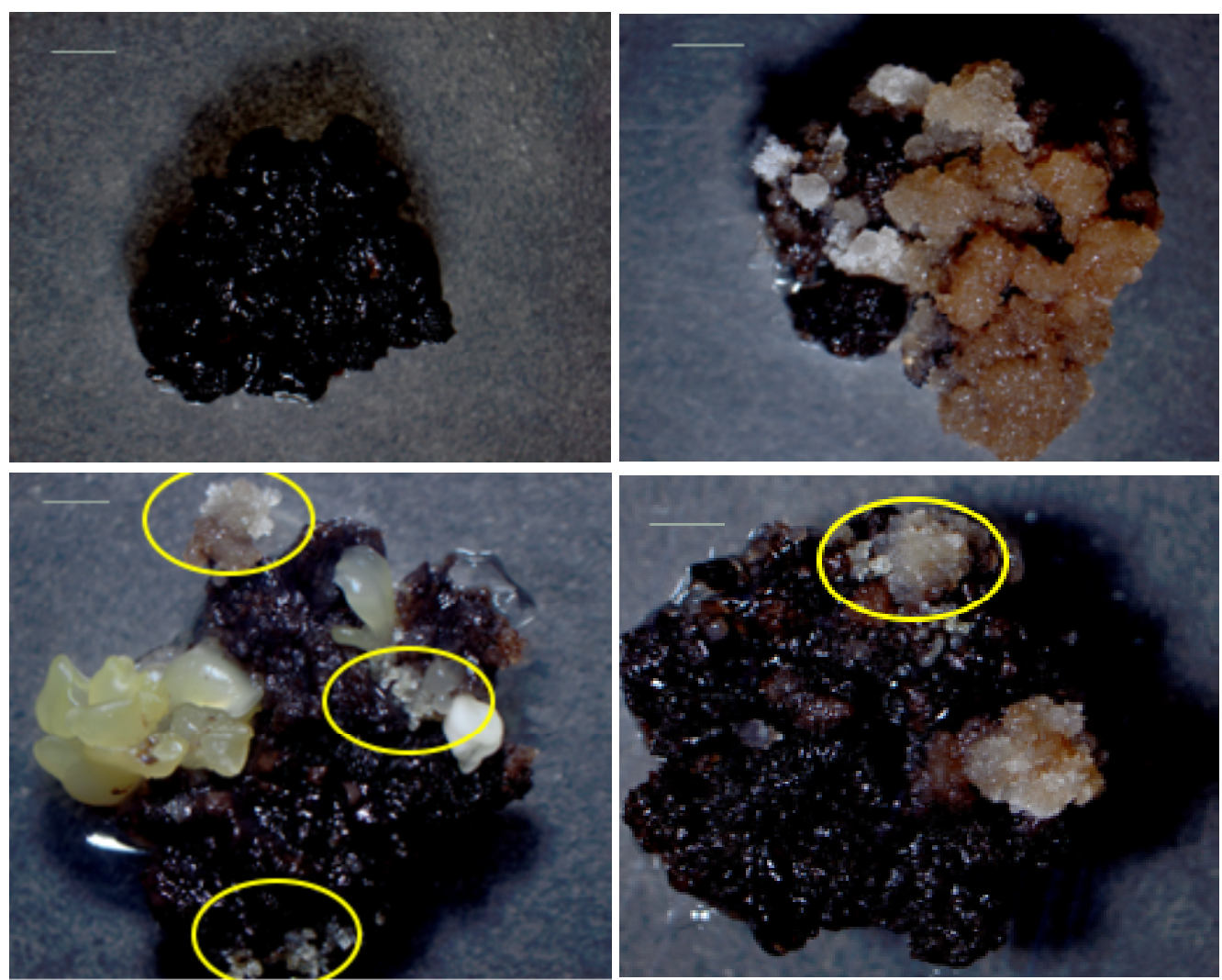

Figure 1. Browning on callus biomass culture of cocoa (before treatment) (A \& B). Embryogenic callus after the addition of ascorbic acid treatment (Observations using an Olympus microscope SZ61 equipped with a DP25 camera) (C \& D). Bar $=3,75 \mathrm{~mm}$ 

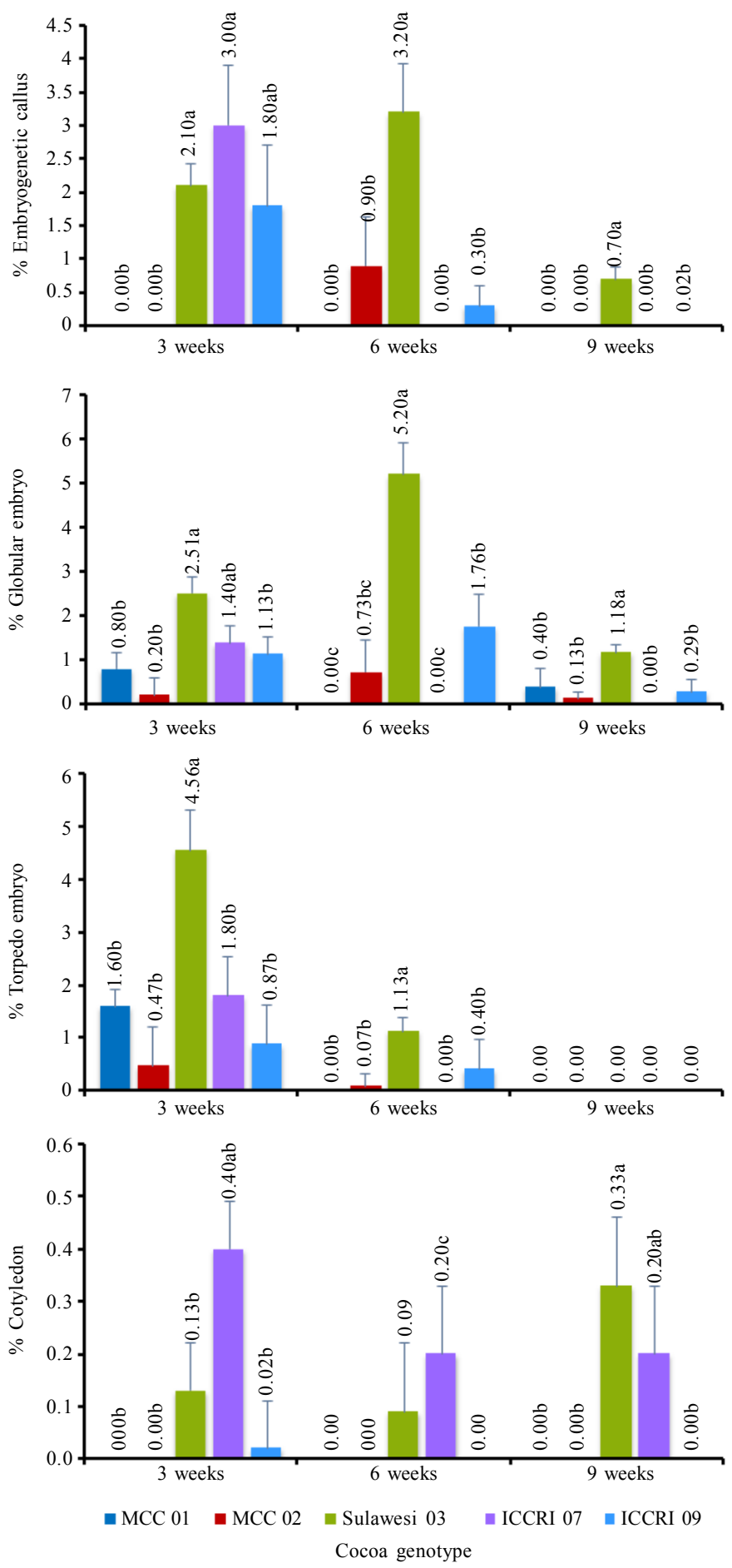

Figure 2. Response of some cocoa clones to the addition of organic acids and hormones 2,4,5-T at the initiation stage of secondary embryogenesis 
Pancaningtyas
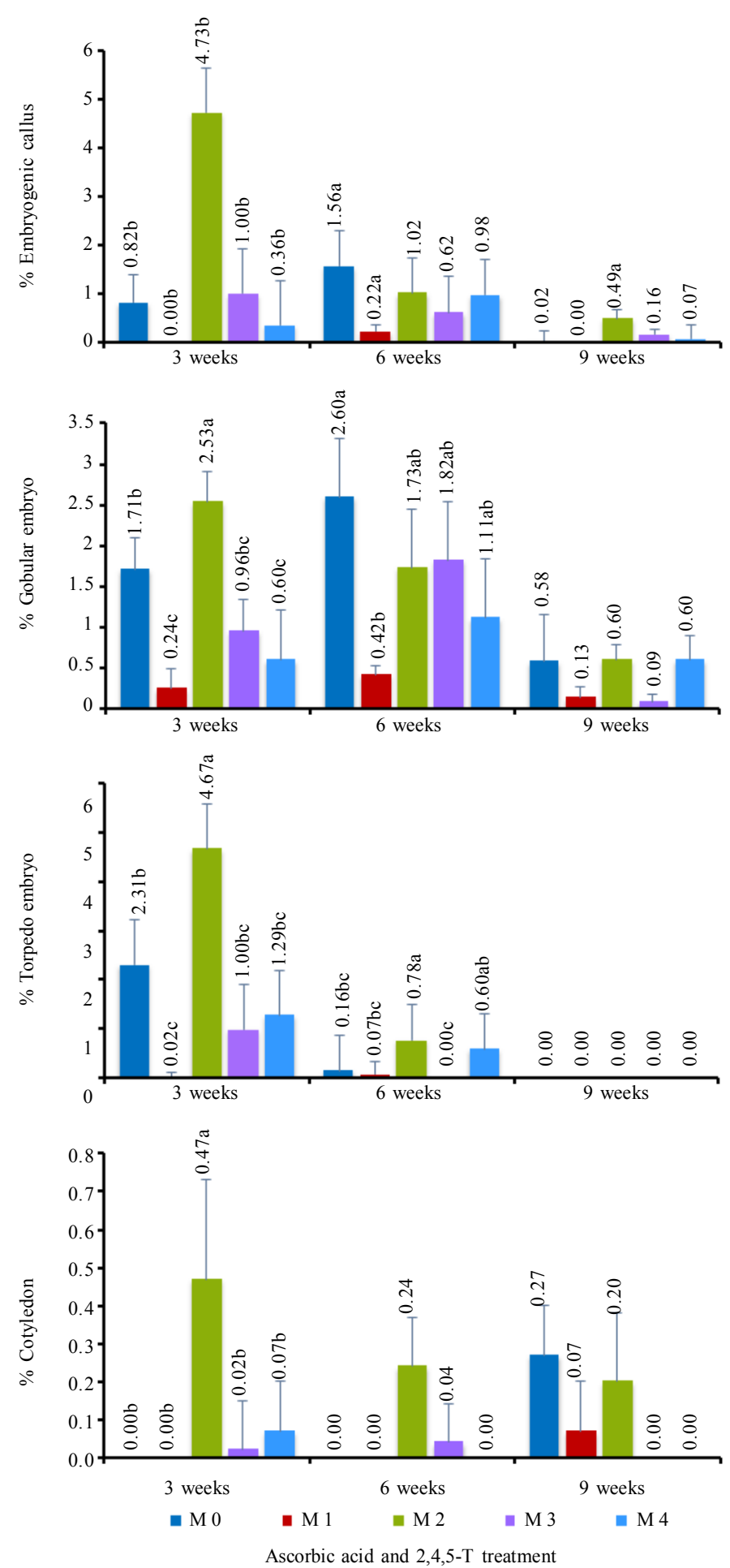

Figure 3. Effect of ascorbic acids and 2,4,5-T concentration on the initiation of secondary embryogenesis

Notes: $\quad$ M1 (ascorbic acid $100 \mathrm{mg} . \mathrm{L}^{-1}+2,4,5-\mathrm{T} 0.5 \mathrm{mg}$. $\mathrm{L}^{-1}$ ); $\mathrm{M} 2$ (ascorbic acid $100 \mathrm{mg} . \mathrm{L}^{-1}+2,4,5-\mathrm{T} 1$ mg.L $\mathrm{L}^{-1}$ ); M3 (ascorbic acid $200 \mathrm{mg} . \mathrm{L}^{-1}+2,4,5-\mathrm{T} 0.5 \mathrm{mg} . \mathrm{L}^{-1}$ ); M4 (ascorbic acid $200 \mathrm{mg} . \mathrm{L}^{-1}+$ 2,4,5-T $\left.1 \mathrm{mg} \cdot \mathrm{L}^{-1}\right)$. 
on the regeneration response of cocoa secondary somatic embryos. Nonetheless, there is no interaction between genotype and culture media. This is also related to the physiological conditions of the cultured cells or tissues.

The addition of 2,4,5-T hormone combined with ascorbic acid affected the initiation of cocoa secondary somatic embryogenesis. The treatment combination of ascorbic acid $100 \mathrm{mg} . \mathrm{L}^{-1}$ and 2,4,5-T $1 \mathrm{mg} . \mathrm{L}^{-1}$ had a significant effect on the initiation of secondary somatic embryogenesis of cocoa in both embryogenic callus phase (4.73\%), globular embryos (2. 53\%), torpedo embryos (4.67\%) and planlets $(0.47 \%)$ (Figure 3$)$. That treatment medium still showed good results even up to the observation at week nine. In other treatment mediums, embryogenic callus and globular embryos showed an increase in the $6^{\text {th }}$ week. The combination of ascorbic acid $100 \mathrm{mg} . \mathrm{L}^{-1}$ and 2,4,5-T $0.5 \mathrm{mg} . \mathrm{L}^{-1}$ treatment showed the lowest values in all parameters (embryogenic callus, globular embryos, torpedo embryos, and planlets).

Browning intensity in culture is influenced by plant species and varieties, tissues or organs, plant development phase, tissue or organ age, nutrient media, and other tissue culture variables (Huang et al., 2002; Chandra et al., 2005). Based on Jakhar et al. (2013), the addition of $100 \mathrm{mg} . \mathrm{L}^{-1}$ ascorbic acid can suppress browning intensity and increase shoot induction in vitro. The addition of ascorbic acid to the culture medium was also used to overcome browning in some in-vitro cultures of banana plants (Ko et al., 2009; Munguatosha et al., 2014).

\section{Embryogenic Callus Regeneration and Somatic Embryo}

Browning in tissue greatly affects the decline in-vitro regeneration of callus and organ cultures, including the process of somatic embryogenesis. The addition of organic acid (ascorbic acid) to the culture media to overcome browning was also given to the embryo regeneration medium to increase the number of somatic embryos produced. In the first observation ( $3^{\text {rd }}$ weeks), ICCRI 09 clones followed by Sulawesi 03 clones showed the percentage of embryogenic callus formation ( $2 \%$ and $1.7 \%$ ), globular embryos $(4.67 \%$ and $3.08 \%$ ), and torpedo embryos $(4.56 \%$ and $3.47 \%$ ) which were higher than the other clones. In Sulawesi 03 clones embryogenic callus still produced a high percentage until the $9^{\text {th }}$ week (Figure 6). MCC 02 clone showed the lowest embryogenesis response for all observation parameters.

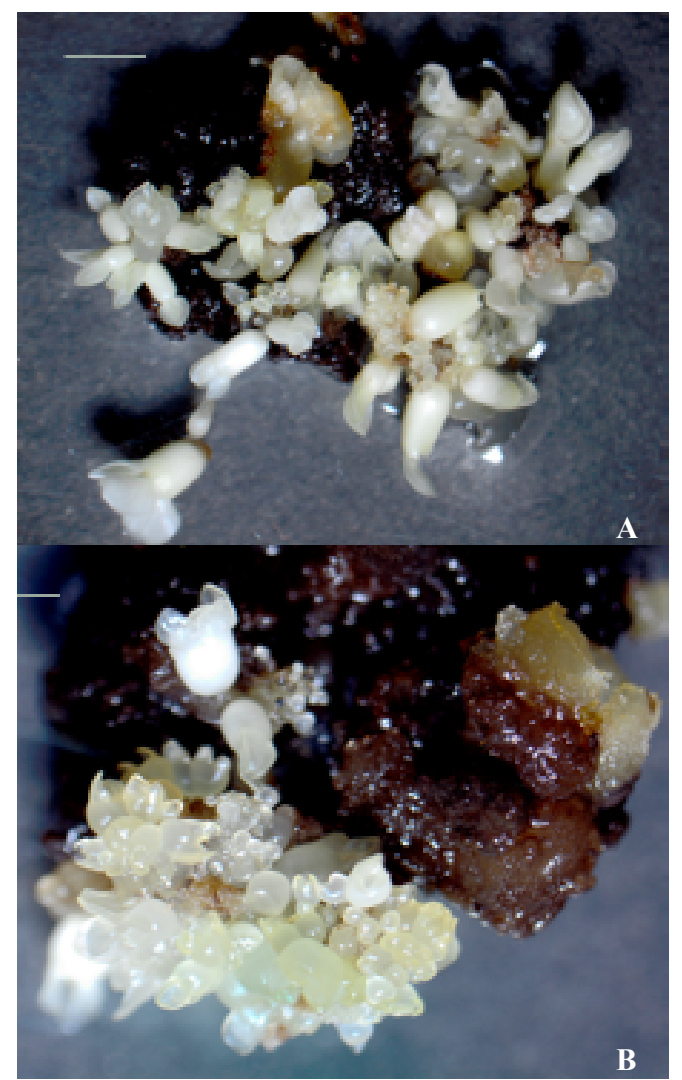

Figure 4. Callus biomass after treatment with $\mathrm{C} 4$ medium (Observations using an Olympus microscope SZ61 equipped with a DP25 camera); A. Bar $=3,75 \mathrm{~mm}, \mathrm{~B}$. Bar $=3 \mathrm{~mm}$ 
Pancaningtyas
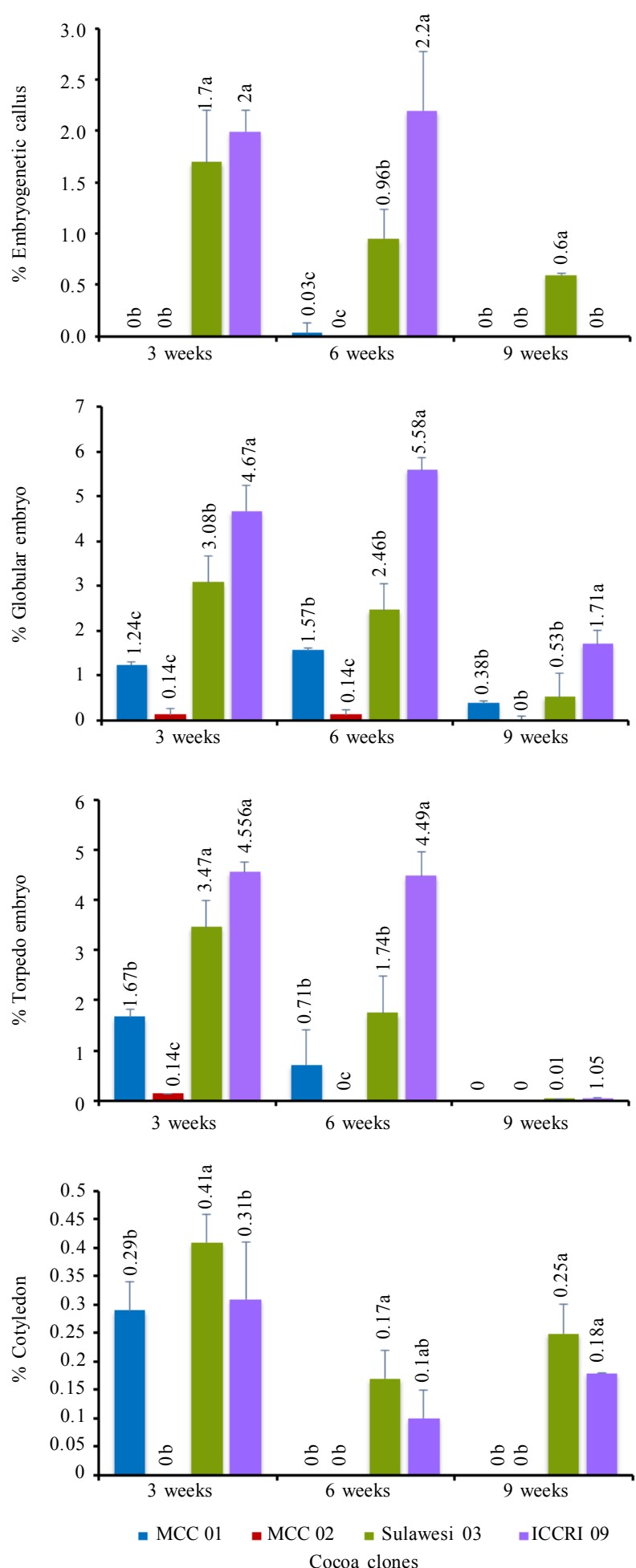

Figure 5. Response of various cocoa clones in terms of embryogenic callus and secondary somatic embryo regeneration 

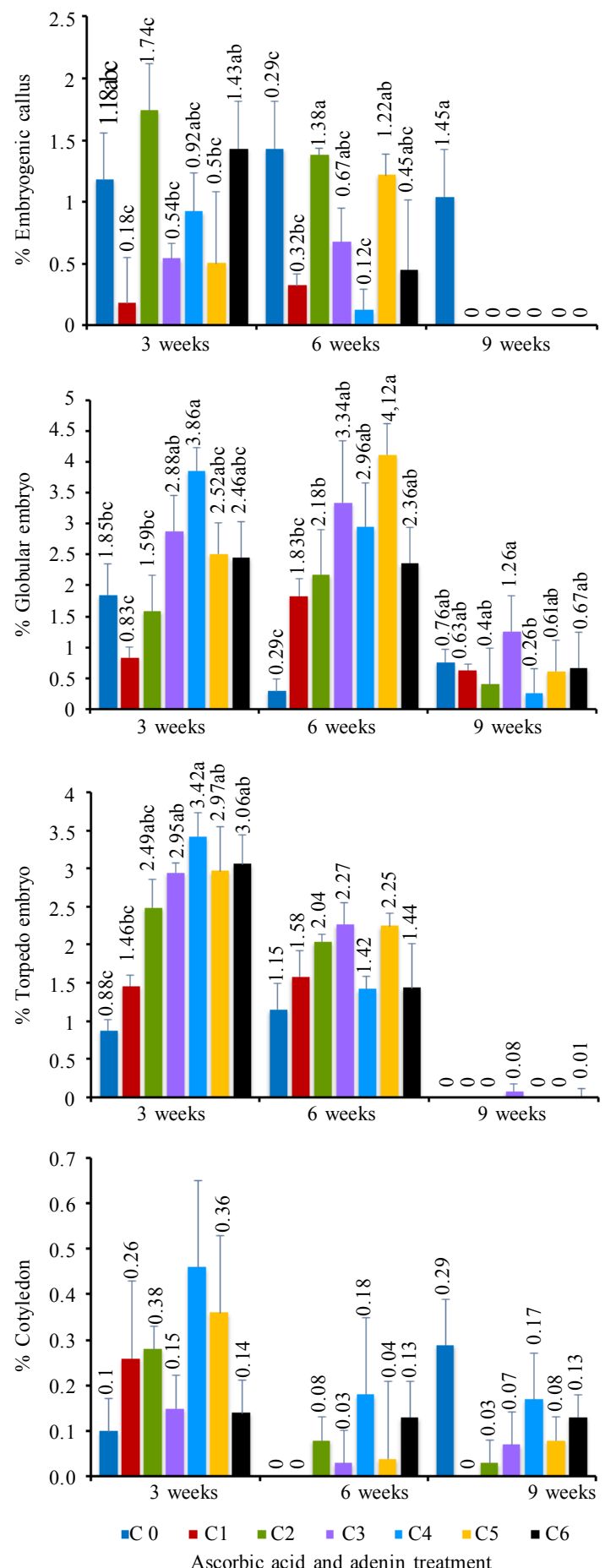

Figure 6. Effect of ascorbic acid and adenine concentration on the regeneration of embryogenic callus and secondary somatic embryos

Notes: Media C0 (Control /expression medium); Media C1 (adenin $0.025 \mathrm{mg} \cdot \mathrm{L}^{-1}+$ ascorbic acid $50 \mathrm{mg} . \mathrm{L}^{-1}$ ); Media C2 (adenin $0.0125 \mathrm{mg} . \mathrm{L}^{-1}+$ ascorbic acid $50 \mathrm{mg} . \mathrm{L}^{-1}$ ); Media C3 (adenin $0.025 \mathrm{mg} . \mathrm{L}^{-1}+$ ascorbic acid $100 \mathrm{mg} . \mathrm{L}^{-1}$ ); Media C4 (adenin $0.0125 \mathrm{mg} . \mathrm{L}^{-1}+$ ascorbic acid $100 \mathrm{mg} . \mathrm{L}^{-1}$ ); Media C5 (adenin $0.025 \mathrm{mg} . \mathrm{L}^{-1}+$ ascorbic acid 150 mg. $\mathrm{L}^{-1}$ ); Media C6 (adenin $0.0125 \mathrm{mg} . \mathrm{L}^{-1}+$ ascorbic acid $150 \mathrm{mg} \cdot \mathrm{L}^{-1}$ ). 
The combination of treatments of ascorbic acid and adenine showed a low embryogenic callus responses in MCC 01 and MCC 02 clones. However, MCC 02 clones also did not show a response to globular, torpedo, and shoot growth phase somatic embryo regeneration. This indicates that different plant cultivars show different responses to the addition of organic acids. The treatment combination of adenine $0.0125 \mathrm{mg} . \mathrm{L}^{-1}$ and ascorbic acid $100 \mathrm{mg} . \mathrm{L}^{-1}$ ) gave the best response to the regeneration of somatic embryos in the globular, torpedo, and shoot growth phases starting 3 weeks after being transferred to regeneration media. Increasing the concentration of organic acids did not affect the increase in the percentage of embryogenic callus.

Dubravina et al. (2005) in their research stated that high phenolic compounds in callus can cause explant tissue death. In guava plant micropropagation, browning can inhibit morphogenesis activity (Chandra \& Mishra, 2007). The high activity of POD and PPO can suppress or even inhibit the development of somatic embryos in undifferentiated callus (Beruto et al., 1996).

The addition of ascorbic acid antioxidants to in vitro culture media can reduce the occurrence of browning. In this case, ascorbic acid does not interact directly with PPO but inhibits browning by reducing substrate oxidation (Arias et al., 2007). Oxidation due to the exudation of phenolic compounds can cause browning of the culture media which will inhibit nutrient uptake in explant tissues. In the study of Jakhar et al. (2019), ascorbic acid treatment of 150-200 mg. $\mathrm{L}^{-1}$ can increase the proliferation of embryogenic callus in Commiphora wightii plants.

\section{CONCLUSIONS}

Combination of ascorbic acid $100 \mathrm{mg} . \mathrm{L}^{-1}$ and 2,4,5-T $1 \mathrm{mg} . \mathrm{L}^{-1}$ had a significant effect on the initiation of secondary somatic embryo- genesis of cocoa in both embryogenic callus phase $(4.73 \%)$, globular embryos $(2.53 \%)$, torpedo embryos $(4.67 \%)$ and germination stages $(0.47 \%)$. ICCRI 07, Sulawesi 03, and ICCRI 09 clones showed a higher percentage of embryogenic callus growth than the other clones. Meanwhile, on MCC 01 clone, all treatments did not affect the regeneration of embryogenic callus. The combination treatment of organic acid and adenine showed a low embryogenic callus response in MCC 01 and MCC 02 clones. However, MCC 02 clones also did not show a response to globular, torpedo, and germination phase somatic embryo regeneration. This indicates that different plant cultivars show different responses to the addition of organic acids. The treatment combination of adenine $0.0125 \mathrm{mg} . \mathrm{L}^{-1}$ and ascorbic acid $100 \mathrm{mg} . \mathrm{L}^{-1}$ gave the best response to the regeneration of somatic embryos in the globular, torpedo, and germination stages, started 3 weeks after being transferred to regeneration medium.

\section{REFERENCES}

Ahmad, I.; T. Hussian; I. Ashraf; M. Nefees; M.R. Marayam; M. Rafay \& M. Iqbal (2013). Lethal effects of secondary metabolites on plant tissue culture. American-Eurasian Journal of Agricultural and Environmental Sciences, 13, 539-547.

Alemanno, L;; T. Ramos; A. Gargadenec; C. Andary $\&$ N. Ferrière (2003). Localization and identification of phenolic compounds in Theobroma cacao L. somatic embryogenesis. Annals of Botany, 92(4), 613-623.

Arias, E.; J. González-Buesa; J.M. Peiró; R. Oria \& P. López Buesa (2007). Browning prevention by ascorbic acid and 4 hexylresorcinol: Different mechanisms of action on polyphenol oxidase in the presence and in the absence of substrates. Journal of Food Science, 72.

Benson, E.E. (2000). Special symposium: In vitro plant recalcitrance. An introduction. 
In Vitro Cellular Developmental Biology Plant., 36, 141-148.

Beruto, M.; G. Cane \& P. Debergh (1996). Field performance of tissue cultured plants of Ranunculus asiaticus L. Scientie Horticulture, 66, 229-239.

Chandra, R. \& M. Mishra (2005). Biotechnological interventions for improvement of guava (Psidium guajava L.). pp. 117-125. In: First International Guava Symposium.

Chandra, R. \& M. Mishra (2007). Biotechnological interventions for improvement of guava (Psidium guajava L.). Acta Horticulture, 735, 117-125.

da Silva, T.E.R.; L.C. Cidade; F.C. Alvim; J.C.D.M. Cascardo \& M.G.C. Costa (2008) Somatic embryogenesis and plant regeneration in elite clones of Theobroma cacao. Brazilian Journal of Agricultural Research, 43, 1433-1436.

Driver, J.A. \& A.H. Kuniyuki (1984). In-vitro propagation of paradox walnut root stock. HortScience, 19, 507-509.

Dubravina, G.; S. Zaytseva \& N. Zagoskina (2005). Changes in formation and localization of phenolic compounds in the tissues of European and Canadian Yew during dedifferentiation in vitro. Russian Journal of Plant Physiology, 52, 672-678.

Figueira, A. \& J. Janick (1995). Somatic embryogenesis in cacao (Theobroma cacao L.). pp. 291-310. In: Somatic Embryogenesis in Woody Plants (Jain, S.; P. Gupta \& R. Newton, eds).

Gallego Rua, A.M.; A.M. Henao Ramirez; A.I. Urrea Trujillo \& L. Atehortua Garces (2016). Polyphenols distribution and reserve substances analysis in cacao somatic embryogenesis. Acta Biológica Colombiana, 21(2), 335-345.

Huang, L.C.; Y.L. Lee; B.L. Huang; C.I. Kuo \& J.F. Shaw (2002). High polyphenol oxidase activity and low titratable acidity in browning bamboo tissue culture. In Vitro Cellular Developmental Biology Plant, 38, 358.
ICCO (2020). Quarterly Bulletin of Cocoa Statistics, Vol. XLVI - No. 1-Cocoa year 2019/ 20. International Cocoa Organization.

Issali, A.E.; A. Traoré; J.A.K. Ngoran; K.E. Koffi \& A. Sangare (2008). Relationship between some phenological parameters and somatic embryogenesis in Theobroma cacao (L.). Journal Crop Science Biotecnology, 11, 23-30.

Jakhar, M.L.; R. Verma \& D. Dixit (2019). Effect of antioxidants on in vitro degree of browning and culture establishment of Guggul (Commiphora wightii (Arnott)): A valuable desert medicinal plant. Journal of Pharmacognosy and Phytochemistry, 5, 250-254.

Jakhar, M.S.; P.K. Vaish \& S. Pathak (2013). Studies on the standardization and preservation of guava (Psidium guajava L.) and barbados cherry (Malpighia glabra L.) blended ready-to-serve beverage. Progress Horticulture, 45, 95-99.

Jones, A.M. \& P.K. Saxena (2013). Inhibition of phenylpropanoid biosynthesis in Artemisia annua L.: A novel approach to reduce oxidative browning in plant tissue culture. PLOS ONE, 8, 1-13.

Ko, W.; C. Su; C. Chen \& C. Chih-Ping (2009). Control of lethal browning of tissue culture plantlets of Cavendish banana cv. Formosana with ascorbic acid. Plant Cell Tissue and Organ Culture, 96, 137-141.

Kouassi, M.K.; J. Kahia; C.N.G. Kouame; M.G. Tahi \& E.K. Koffi (2017). Comparing the effect of plant growth regulators on callus and somatic embryogenesis induction in four elite Theobroma cacao L. genotypes. HortScience, 52, $142-145$

Krishna, H.; R.K. Sairam; S.K. Singh; V.B. Patel; R.R. Sharma; M. Grover; L. Nain \& A. Sachdev (2008). Mango explant browning: Effect of ontogenic age, mycorrhization and pre-treatments. Scientia Horticulturae, 118(2), 132-138.

Lopez, C.M.R.; H.S. Bravo; A.C. Wetten \& M.J. Wilkinson (2010). Detection of 
somaclonal variation during cocoa somatic embryogenesis characterised using cleaved amplified polymorphic sequence and the new freeware Artbio. Molecular Breeding, 25(3), 501-516.

Maximova, S.N.; L. Alemanno; A. Young; N. Ferriere; A. Traore \& M. Guiltinan (2002). Efficiency, genotypic variability, and cellular origin of primary and secondary somatic embryogenesis of Theobroma cacao L. In Vitro Cellular Developmental Biology Plant, 38, 252-259.

Modeste, K.K.; M.T. Eliane; K. Daouda; S.A. Brahima; K. Tchoa; K.E. Kouablan \& K. Mongomak (2017). Effect of antioxidants on the callus induction and the development of somatic embryogenesis of cocoa (Theobroma cacao L.). Australian Journal of Crop Science, $11,25-31$.

Munguatosha, N.; M. Emerald \& N. Patric (2014). Control of lethal browning by using ascorbic acid on shoot tip cultures of a local Musa spp. (banana) cv. mzuzu in Tanzania. African Journal of Biotechnology, 13, 1721-1725.

Murashige, T. \& F. Skoog (1962). A revised medium for rapid growth and bioassays with tobacco tissue cultures. Physiology Plantarum, 15, 473-497.

Pancaningtyas, S. (2013). Evaluation of quantity and hyperhydricity of cocoa somatic embryo obtained from solid culture, liquid culture, and sequence subculture. Pelita Perkebunan, 29, 10-19.
Pancaningtyas, S. (2015). Study on the presence and influence of phenolic compounds in callogenesis and somatic embryo development of cocoa (Theobroma cacao L.). Pelita Perkebunan, 31(1), 14-20.

Quainoo, A.K. \& B.I. Dwomo (2012). The effect of TDZ and 2, 4-D concentrations on the induction of somatic embryo and embryogenesis in different cocoa genotypes. Journal of Plant Science, 1, 72.

Sonwa, D.J. (2002). Etude de cas d'aménagement forestier exemplaire en Afrique centrale: Les systèmes agroforestiers cacaoyers Cameroun.

Squicciarini, M.P. \& J. Swinnen (2016). The economics of chocolate. Journal of Wine Economics, 11(3), 471-475.

Towaha, J. \& E. Wardiana (2015). Evaluasi tingkat toleransi 35 genotipe kakao terhadap periode kering. Jurnal Tanaman Industri dan Penyegar, 2, 133-142.

Wickramasuriya, A.M. \& J. Dunwell (2018). Cacao biotechnology: current status and future prospects. Plant Biotechnology Journal, 16(1), 4-17.

$$
* * 0 * *
$$

